\title{
1 Valorization of deinking sludge as a substrate for lignocellulolytic 2 enzymes production by Pleurotus ostreatus
}

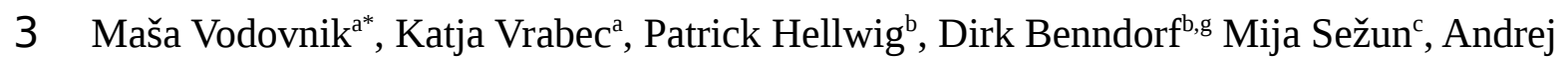

$4 \quad$ Gregori $^{\mathrm{d}}$, Lalitha D. Gottomukkala ${ }^{\mathrm{e}}$, Robin C. Anderson ${ }^{\mathrm{f}}$, Udo Reichl ${ }^{\mathrm{b}, \mathrm{g}}$

$5^{\mathrm{a}}$ Chair of Microbiology and Microbial Biotechnology, Biotechnical Faculty, University of Ljubljana, 6Domžale, Slovenia

$7^{\text {b }}$ Institute of Process Engineering, Otto von Guericke University Magdeburg, Magdeburg, Germany

8 Pulp and Paper Institute, Ljubljana, Slovenia

9d MycoMedica d.o.o, Kranjska Gora, Slovenia

10 Celignis Limited, University of Limerick, Limerick, Ireland

$11^{\mathrm{f}}$ United States Department of Agriculture, Southern Plains Agricultural Research Center, Food and 12Feed Safety Research Unit, College Station, Texas

$13^{\mathrm{g}}$ Max Planck Institute for Dynamics of Complex Technical Systems, Germany

\section{4}

15 * Corresponding author:

16masa.vodovnik@bf.uni-lj.si

17

18

19

20

21

22

23 


\section{Abstract}

25Disposal of waste sludges produced in large amounts in the pulp and paper industry imposes 26significant environmental and economical problems. One strategy to address these issues 27involves revalorization of paper mill sludges by their application as substrates for microbial 28production of biotechnologically relevant enzymes. The application of lignocellulolytic 29enzymes in paper, textile and bioenergy industries is encouraged in order to decrease 30chemicals and energy consumptions. In the following work, deinking sludge was assessed as a 31substrate for production of lignocellulases. Based on the results of growth and activity 32screenings, Pleurotus ostreatus PLAB was chosen as the most promising candidate among 30 33tested strains and its secretome was further studied by quantitative enzyme assays and mass 34spectrometry. While endoglucanase and xylanase activities detected in P. ostreatus secretome 35produced on deinking sludge were similar to activities of cultures grown on other 36lignocellulosic substrates, average laccase activity was significantly higher (46 000 U / kg Dis). 37Mass spectrometry identification of the most prominent proteins in the secretome of the target 38strain confirmed that significant amounts of different lignin-modifying oxidases were 39 produced on this substrate despite its low lignin content, indicating the presence of other 40inducible compounds. The findings of this study suggest deinking sludge may represent a 4lgood substrate for fungal production of the aforementioned enzymes with broad 42biotechnological applications, including bioremediation, paper and bioenergy industries.

43Key words: paper mill waste / deinking sludge / fungi / lignocellulolytic enzymes / solid-state 44fermentation 
47Abbreviations: DIS - deinking sludge, SF - submerged fermentation, SSF - solid state 48fermentation, TOC - total organic carbon, TON - total organic nitrogen, WRF - white rot 49fungi, PDA - potato dextrose agar, SEEs - secreted enzyme extracts, CMC - carboxymethyl 50cellulose, BX - birchwood xylan, EG - endoglucanase, EX - endoxylanase, ABTS - 2,2'51azino-bis (3-ethylbenzothiazoline-6-sulphonic acid), PDA - potato dextrose agar, SDS PAGE 52- sodium dodecyl sulphate polyacrylamide gel electrophoresis, TCA - trichloroacetic acid, 53LC MS/MS - liquid chromatography coupled to tandem mass spectrometry

\section{4}




\section{Introduction}

56Eleven million tonnes of waste are produced yearly by the European pulp and paper industry 57(Monte et al., 2009). Approximately 70\% of these originate from manufacturing tissue paper 58from recovered fibre, leading to the generation of considerable amounts of deinking sludge 59(150 kg dry solids/t paper manufactured), which must be properly managed to avoid negative 60effects on the environment (Deviatkin et al., 2016). Deinking sludge (DIS) exists as a mixture 61 of short cellulosic fibers and inorganic fillers, such as calcium carbonate and china clay, and 62residual chemicals dissolved in water (Likon and Saarela, 2012). DIS originating from printed 63recycle mills is high in ash content compared to sludge originating from corrugated recycle 64mills and virgin pulp mills (Boshoff et al., 2016).

65Traditional methods of DIS management include landfilling, landspreading, composting, 66incineration and pyrolysis, utilisation as construction material and landfill capping material 67(Likon and Trebše, 2012). However, due to high moisture content some of these recovery 68methods, such as incineration and pyrolysis, are expensive for large amounts of sludge while 69the environmental impact of others is questionable due to the possibility of hazardous 70substances leaking into the environment. As a result, numerous possibilities for biological 71 valorisation of paper sludge waste, including its fermentation and anaerobic digestion are 72currently being explored (Gottomukkala et al., 2016). These aim for efficient microbial 73transformation of cellulose waste into bioethanol (Boshoff et al., 2016), biomethane (Mohan 74et al., 2016a), biohydrogen or other value added chemicals (Liguori and Faraco, 2016).

75The main advantage of exploiting paper sludges as sources of cellulose-derived energy and 76chemicals in comparison to other lignocellulose substrates is their amenability, which is 77associated with an extensive pulping process that removes the majority of the lignin and 78exposes cellulose fibers to enzymes. This results in substantial cost savings on energy for 79substrate pretreatment in comparison to other lignocellulose fuel production technologies 
80(Gottumukkala et al., 2016). Studies on direct production of bioethanol from paper sludge 81have shown that tissue printed recycle sludge (a type of DIS) resulted in significantly lower 82ethanol yields when compared to corrugated recycle and virgin pulp mill sludges (Williams 832017), so other possible ways for valorization of this type of substrate need to be explored. 84 One of the major limiting factors for bioconversion of cellulosic waste such as paper sludge 85to valuable products is the cost of the enzymes, as they are commercially produced using high 86cost feedstocks. Reducing the enzyme dosage per gram cellulose/feedstock has been a major 87research area for the past few years (Robus et al., 2016). Efficient transformation of cellulosic 88 feedstock to value added products requires a mix of synergistically acting enzymes 89(CAZYmes) that are able to work at low dosages. White-rot fungi (WRF) are known to 90produce significant amounts of powerful extracellular oxidative and hydrolytic enzymes that 91degrade lignin and cellulose biopolymers (Manavalan et al., 2015). Major functional groups 92of glycoside hydrolases (cellulases and hemicellulases) produced by WRF involve 93endoglucanases (EG; EC 3.2.1.4), cellobiohydrolases (EC 3.2.1.91, EC 3.2.1.176), beta94glucosidases (3.2.1.21), endoxylanases (EX; EC 3.2.1.8), beta-xylosidases (EC 3.2.1.37) and 95alpha-glucuronidases (E.C. 3.2.1.131). On the other hand, lignin degradation enzyme systems 96are based on oxidative enzymes, such as lignin peroxidases (EC 1.11.1.14), manganese 97peroxidases (EC 1.11.1.13), versatile peroxidases (EC1.11.1.16), and laccases (EC 1.10.3.2) 98(Manavalan et al., 2015). Recently, oxidative enzymes, namely lytic polysaccharide 99monooxygenases, have also been shown to play an important role in the degradation of 100cellulose (Garajova et al., 2016). The composition of the enzyme mixtures produced on 101different substrates (ratios between different types of enzymes) reflects substrate composition 102(Elisashvili et al., 2008).

103The applications of fungal enzymes in paper industry involve biobleaching of pulp, pulp de104inking, degradation of dissolved and suspended organic compounds in concentrated effluents 
105of mills and enhanced fibrillation. Enzymes usage is encouraged in paper industry in order to 106reduce the use of chemicals and energy consumption as well as to improve quality of the 107products (Bajpai, 2014). A desirable side-effect of processing paper mill waste by WRF 108enzymes is non-specific degradation of organic environmental pollutants, commonly present 109in these substrates (Kües, 2015).

110Most industrial enzymes currently produced by fungi are products of submerged fermentation 111 (SF) which uses significant amounts of water and generates large quantities of liquid waste 112stream during the filtration process. Major cost contributor in commercial cellulase 113 production is cost of the feedstock which is mostly glucose and accounts for $50 \%$ of the total 114process cost (Humbird et al., 2011). However, solid state fermentation (SSF) has emerged as 115an economically attractive alternative for the in situ production of lignocellulolytic enzymes 116due to lower energy consumption, direct use of low-cost lignocellulosic wastes as substrates, 117reduction in cost of dewatering in downstream processing, higher concentrations of enzymes 118and lower demand for the sterility of the equipments (Yoon et al., 2014). At present, the 119production of lignocellulolytic enzymes by SSF on several agricultural wastes has been 120reported, such as coffee pulp (Velazquez-Cedeno et al., 2002), spend brewery grains (Gregori 121et al., 2008), straw and fruit peels (Kurt and Buyukalaca, 2010), rice straw (Khalil et al., 1222011) and tomato pomace (Iandolo and Piscitelli, 2011). Conversely, there are few reports on 123enzyme production from paper sludge and no report specifically on fungal enzymes 124production from deinking paper sludge.

125The aim of the following work was to untap the potential of DIS as a low-cost substrate for 126fungal production of lignocellulolytic enzymes via SSF. Fungal strains with the ability to 127 transform the unpretreated DIS to a mixture of industrially relevant lignocellulases were 128identified. Furthermore, the composition, production dynamics and performance of the 129extracted enzymes were studied in detail in the most promising of the tested strains $(P$. 
130ostreatus $P L A B)$. The advantages of lignocellulolytic enzymes production on DIS and their

131applications in different industries is also discussed from a perspective of cleaner production.

132

\section{Materials and methods}

\subsection{Substrate characterization}

135DIS was obtained from a paper mill in Vipap, Krško, Slovenia. After the substrate was sieved 136through a mesh with $0.9 \mathrm{~cm}$ openings, its $\mathrm{pH}$ and moisture content were measured (Kern

137MLS-D). For the determination of cellulose, hemicellulose and lignin content of the substrate, $13810 \mathrm{~g}$ of air-dried DIS was first mixed with $200 \mathrm{ml}$ of $6 \mathrm{M} \mathrm{HCl}$ and than incubated for $1 \mathrm{~h}$ to 139dissolve the inorganic fraction. Following filtration and drying, the cellulose content of DIS 140was determined according to the method described in Kurschner and Hoffer (1993), 141hemicellulose content as described in Wise and Karl (1962) and lignin content according to 142the method as described in Fukushima et al., 2015. Dry content was measured according to 143European standard SIST EN 14346:2007, total organic carbon (TOC) according to standard 144SIST EN 13137:2002, total organic nitrogen (TON) according to persulfate digestion method 14510071 (Test'N Tube, Hach Lange). Heavy metals were determined according to the following 146standards: DIN 38406-E7-2:1991 (Cu), SIST ISO 8288:1996 (Zn), DIN 38406-E11-2:1991 147(Ni), SIST EN ISO 5961:1996 (Cd), SIST ISO 5666:2000 (Hg), SIST ISO 9174:1999 (Cr), 148DIN 38406-E6-2:1998 (Pb).

\subsection{Screening of fungal strains based on growth efficiency on DIS}


154Thirty fungal strains of different origin obtained from culture collection Mycomedica d.o.o.

155(Suppl. 1) were first screened for their growth on agar plates incorporating the target substrate 156(DIS agar). The strains were stored as slant test tubes on Potato Dextrose Agar (PDA, Difco, 157USA) at $3{ }^{\circ}$. Before each experiment, mycelium from each fungal strain was transferred to 158PDA agar and incubated in the darkness at $23^{\circ} \mathrm{C}$ until overgrowing the entire surface. A $9 \mathrm{~mm}$ 159diameter disc was cut from the resultant mycelium and used to inoculate a DIS agar plate. DIS 160agar, prepared by mixing bacteriological agar (Sigma), deinking sludge and distilled water in 161ratio 1:10:100, was autoclaved for $20 \mathrm{~min}$ at $121^{\circ} \mathrm{C}, 1.1$ bar. Additional sets of media were 162prepared similarly except without autoclaving in order to test the growth on non-pretreated 163substrate (energetically favourable option). All strains were inoculated in triplicates and their 164growth was observed for 50 days and classified in different categories according to its 165efficiency. Ten strains with the highest average growth rate on DIS agar were chosen for 166further enzyme activity screenings.

\subsection{Enzyme activity screening}

169Based on the highest growth rates achieved on DIS agar, 10 strains were selected for 170additional semi-quantitative screening for endoglucanase, xylanase and laccase activities. 171Secreted enzyme extracts (SEEs) were prepared by first homogenizing the overgrown DIS 172agar by Ultraturax disperser (Ika) at $1000 \mathrm{rpm}$ for $5 \mathrm{~min}$. Aliquotes (20 $\mathrm{ml})$ of homogenate 173were mixed with equal amounts of $0.5 \mathrm{M} \mathrm{Na}$-phosphate buffer $\mathrm{pH} 7$ and shaken on ice at 150

174rpm for $3 \mathrm{~h}$. Following centrifugation at $18500 \mathrm{x}$ g, the clear supernatants (representing SEEs) 175 were transferred to sterile Falcon tube and stored at $-20^{\circ} \mathrm{C}$ until further use. Aliquots of $10 \mu \mathrm{L}$ 176of SEEs from different fungal strains were applied in the hollow areas of equal size $(0.5 \mathrm{~mm}$ 177 diameter) wells cut into $0.6 \%$ (w/v) agarose plates incorporating target substrates. The 178following substrates were used: $0.2 \%$ (w/v) carboxymethyl cellulose (CMC) when screening 
179 for endoglucanase activity, 0.4\% (w/v) birchwood xylan (BX), when screening for xylanase 180activity and $0.4 \%(\mathrm{v} / \mathrm{v})$ guaiacol when screening for laccase activity. SEEs denatured by 181heating at $100{ }^{\circ} \mathrm{C}$ for 15 min were used as negative controls. The plates were incubated at $18230{ }^{\circ} \mathrm{C}$ for $4 \mathrm{~h}$. Guaiacol plates were assessed directly by measuring radius of brown areas that 183developed around wells with applied SEEs due to laccase activity. Plates incorporating CMC 184and BX were stained by Kongo red for 30 min and subsequently washed by $1 \mathrm{M} \mathrm{NaCl}$ 185(Teather and Wood, 1982). The radii of clear zones indicating substrate degradation were 186measured and compared in order to assay xylanase and endoglucanase activities in SEEs from 187different fungal strains. Based on growth and enzyme screening, P. ostraetus PLAB was 188selected for further investigation.

189

\subsection{Enzymes production and extraction from deinking paper sludge (DIS)}

191P. ostreatus PLAB mycelia were first inoculated to PDA media in petri dishes as described in 192the section 2.2. After suspending in distilled water, $5 \mathrm{ml}$ of mycelium was used to inoculate $193200 \mathrm{~g}$ of each sterilized DIS medium (prepared by sieving DIS trough the mesh and adjusting 194its moisture content to $65 \%(\mathrm{w} / \mathrm{w})$ in 1 L glass jars. Uninoculated DIS medium was used as a 195negative control. Jars were incubated at $23^{\circ} \mathrm{C}$ until mycelial growth was observed. For 196enzyme activity quantification, cultures were incubated for 51 days and collected in 7 day 197intervals (first sampling took place after mycelium started to grow in all of the samples). Four 198cultures were collected at each time point and frozen for further analysis. Following 199homogenization, selected buffers were added to each homogenate at the ratio 1:1. Based on 200literature and preliminary experiments, $0.5 \mathrm{M}$ acetate buffer $\mathrm{pH} 4$ was used for laccase, $0.5 \mathrm{M}$ 201acetate buffer pH 5 for endoglucanase (EG) and 0.5 M citrate buffer pH 6 for xylanase 202extraction. Extraction was performed by incubating the samples on ice for $3 \mathrm{~h}$ with 203intermittent mixing by Vortex (every 30 min for 30 s). 
204Following centrifugation at 18500 x g, clear supernatant (representing SEEs) was separated, 205aliquoted and stored at $-20{ }^{\circ} \mathrm{C}$ until further processing.

206

2072.5. Spectrophotometric assays for quantitative determination of total protein, 208endoglucanase and xylanase activities in SEEs

209Cellulase (endoglucanase) and xylanase activities in SEEs were measured via quantitative 210determination of released reducing sugars by para-hydroxybenzoic acid (PAHBAH) assay 211(Lever, 1977). Suspensions of 1\% beechwood xylan (BX) in $0.5 \mathrm{M}$ citrate buffer pH 6 (for 212xylanase activity) or 1\% carboxymethyl cellulose (CMC) in $0.5 \mathrm{M}$ acetate buffer pH 5

213(endoglucanase activity) were used as substrates. Twenty $\mu l$ of enzyme extracts were added to $214230 \mu \mathrm{l}$ of substrate suspensions and incubated in microcentrifuge tubes at $30{ }^{\circ} \mathrm{C}$ for $150 \mathrm{~min}$. 215Reactions were stopped by adding $30 \mu \mathrm{l}$ of 15\% trichloroacetic acid (TCA). In control 216samples, enzyme extracts were added after the incubation, just before enzyme inactivation. $217100 \mu \mathrm{l}$ of each incubated sample was added to $5 \mathrm{ml}$ of reaction mixture in test tubes and 218heated in boiling water for $10 \mathrm{~min}$. Absorbance of the mixture was measured at $420 \mathrm{~nm}$. Total 219protein concentrations in SEEs were quantified by Lowry assay, using bovine serum albumin 220(BSA) as a standard (Lowry et al., 1951). Two technical replicates were performed for each 221 sample in order to assess method variability.

222

\subsection{Spectrophotometric assay for quantitative determination of laccase activity in SEEs}

224A modified assay described in Childs and Bardsley (1975) was used to measure laccase 225activities in SEEs. Reaction mixtures (prepared in duplicate) consisted of $100 \mu \mathrm{l} 5 \mathrm{mM}$ 2,2'226azino-bis (3-ethylbenzothiazoline-6-sulphonic acid) (ABTS, Calbiochem), 895 l $0.1 \mathrm{M}$ 227acetate buffer pH 4.5 and $5 \mu$ l enzyme extract. Cooled ABTS was added to the sample after 228heating reaction mixture to $30^{\circ} \mathrm{C}$ and absorbance was measured at $420 \mathrm{~nm}$ continuously. 
229Enzyme extracts previously inactivated by heating at $100{ }^{\circ} \mathrm{C}$ for 20 min were used as negative 230controls.

231

2322.7. SDS-PAGE and mass spectrometry

233Four 30-days old cultures were homogenized and SEEs were prepared by extraction of 234proteins from $20 \mathrm{~g}$ of each homogenate in equal amounts of phosphate buffer ( $\mathrm{pH}$ 8) with the 235addition of protease inhibitors (cOmplete ULTRA Tablets, Sigma-Aldrich) and freeze-dried 236for transport at ambient temperature. Before the analysis, the samples were dissolved in 750 $237 \mu \mathrm{l}$ deionized water and precipitated with the same volume of $20 \%$ TCA at $4{ }^{\circ} \mathrm{C}$ for $1 \mathrm{~h}$. The 238precipitate was collected by centrifugation (16400 x g, $10 \mathrm{~min}, 4^{\circ} \mathrm{C}$ ), subsequently washed 239 twice with $2.25 \mathrm{ml}$ of acetone $\left(15 \mathrm{~min},-20^{\circ} \mathrm{C}\right)$ and $2.25 \mathrm{ml}$ of ethanol $\left(15 \mathrm{~min},-20^{\circ} \mathrm{C}\right)$. After 240air-drying the final precipitates were dissolved in $200 \mu \mathrm{l}$ of urea buffer. The protein 241concentration determination was carried out with Amidoblack (Schweikl et al., 1989) using 242BSA as standard. SDS-PAGE was performed according to Laemmli (1970). After separation, 243the bands were cut from the gel and digested with trypsin as described previously by Heyer et 244al. (2013). The peptides were extracted, dried and resuspended in $11 \mu \mathrm{L}$ of chromatographic 245mobile phase A (98\% LC-MS water, 2\% acetonitrile, 0.05\% trifluoroacetic acid). Five $\mu \mathrm{L}$ of 246sample were injected and separated by UltiMate ${ }^{\circledR} 3000$ nano splitted reversed phase nano 247HPLC (Thermo Fisher Scientific, Dreieich, Germany) equipped with a reversed phase trap 248column (nano trap cartridge, 300 m i.d. x 5 mm, packed with Acclaim PepMap100 C18, 5 249 $\mu \mathrm{m}, 100 \AA$ A, nanoViper, Bremen, Germany) and a reversed phase separation column (Acclaim 250PepMap RSLC, C18, 2 m, 75 m, 15 cm, Bremen, Germany).

251The gradient was $4 \%$ to 55\% mobile phase B (80\% acetonitrile, 20\% LC-MS water, 0.1\% 252 formic acid) over $120 \mathrm{~min}$ at a flow rate of $0.3 \mu \mathrm{L} \mathrm{min}{ }^{-1}$. The amaZon ${ }^{\mathrm{TM}}$ ETD Ion Trap mass 253spectrometer (Bruker Daltonik GmbH, Bremen, Germany) was equipped with a Captive 
254Spray (using acetonitrile) nanoBooster ${ }^{\mathrm{TM}}$ Module and operated in positive ion mode. MS/MS 255data acquisition was performed using collision induced dissociation (CID) with 5 precursor 256ions per measurement and an active exclusion of the same precursor after 2 spectra for 9 257seconds. DataAnalysis 2.0 (Bruker Daltonik) and ProteinScape 3.1.3 461 software (Bruker 258Daltonik) were used for automatic deconvolution and analysis as well as database search 259using Mascot ${ }^{\mathrm{TM}} 2.5$ (Matrix Science, London, UK) in NCBINr database (version 2014/01/22). 2600ne missed cleavage was allowed. Other parameters were chosen as follows: monoisotopic 261mass, variable carbamidomethyl (C) and oxidation (M) modification, 0.3 Da precursor and 262MS/MS tolerance, one ${ }^{13} \mathrm{C}$ and peptide charge of $+2 /+3$.

263

\subsection{Zymograms}

265Separated active glycoside hydrolases in SEEs were detected by modified SDS-PAGE 266(Laemmli, 1970). Separation gels (10\%) were modified by adding $0.2 \%$ (w/v) CMC (for 267detection of endoglucanases) or $0.4 \%(\mathrm{w} / \mathrm{v})$ water soluble fraction of $0.4 \%(\mathrm{w} / \mathrm{v}) \mathrm{BX}$ (for 268detection of xylanases). Enzyme extracts were mixed with equal amounts of loading buffer, 269heated for $6 \mathrm{~min}$ at $85{ }^{\circ} \mathrm{C}$ and applied on $4 \%(\mathrm{w} / \mathrm{v})$ stacking gel. For detection of enzymes 270with laccase activity, native samples were applied on the gels. Glycoside hydrolases were 271renaturated and stained as described previously (Vodovnik and Marinšek Logar, 2012). 272Separated enzymes exhibiting laccase activity were detected by applying ABTS solution 273(Calbiochem, 194430) directly over the gel after its equilibration in 0.1 acetate buffer $\mathrm{pH} 4$ as

274described by Castanera et al. (2012). The properties of the detected enzymes were compared 275to the information on putative P. ostreatus enzymes available in the NCBI protein (Wheeler et 276al., 2002) and BRENDA databases (Schomburg et al., 2004). Where absent, putative 277conserved domains were detected by Interproscan (Quevillon et al., 2005) while other 
278properties of interest (Mw and pI) were calculated using ProtParam tool (Gasteiger et al., 2792005).

280

\subsection{Data processing and statistical analysis}

282Results are presented as the mean \pm standard deviation (SD) of at least 3 replicates. The data 283presentation and analysis were carried out using R version 3.1.3 and Microsoft Excell 2013. 284Statistically significant differences in enzyme activities between different fungi were 285evaluated by one-way ANOVA, while growth-point-related activities analysis was done by 286repeated measures ANOVA (paired samples Student's t-test). A significant difference was 287considered if $\mathrm{p}<0.05$ applying Tukey multiple-comparisons HSD.

288

\section{Results and discussion}

\subsection{Substrate characterization}

291Commercial cellulases are produced using recombinant fungal strains to yield enzyme titres 292of close to $100 \mathrm{~g} / \mathrm{L}$ with superior activity. Inducible carbon sources such as purified cellulose, 293lactose and sophorose are used for high-level cellulase production. Feedstock cost is an 294important consideration for commericail enzyme production as this contributes more than $29550 \%$ of the total cost of the final enzyme (Ellila et al, 2017). Other than cost factor, there are 296also environmental concerns that impact commercial enzyme production as bioprocesses 297using genetically modified organisms, excessive amounts of nutrients used for process 298intensification and use of large quantities of fresh water can adversely affect regulatory costs 299and carbon emissions (Junker, 2010). Utilisation of waste streams rich in cellulose such as 300paper sludge as feedstocks for enzyme production will not only reduce the feedstock cost for 301enzyme production but also support cleaner production by reducing the amounts of waste 
302disposal in comparison to high amounts of nutrient rich liquid and solid waste generated by 303the bioprocess industry that mainly uses pure substrate and nutrient source.

304Deinking paper mill sludge, a major waste stream from the pulp and paper industry, was 305 selected for this study, as it is mainly composed of short cellulose fibers. It also includes 306 fines, inks and other additives that can influence the growth of the microoganisms and 307enzyme production. It has been reported that even among mills using similar processes and 308feedstocks, the sludge composition may vary due to different operating conditions (Williams, 3092017). So DIS used in our study was characterized for its chemical composition.

310DIS used in our study has a moisture content of 39\% and cellulose content of $34.2 \%$.

311 Hemicellulose and lignin contents are $6.2 \%$ and 3.7\% respectively, which were lower than 312stated in previous reports (Gottomukkala et al., 2016). The remaining is mostly ash and heavy 313metals (Table 1). Cellulose is the major carbon source contributor for fungal growth and also 314an inducer of cellulases. Hemicellulose and lignin fractions on the other hand play an 315important role in production of plant biomass-degrading enzyme cocktail including xylanases 316and ligninases (Fernández-Fueyo et al., 2016).

317The high moisture content of DIS is due to the water holding capacity of cellulose fibres in 318the sludge which makes it unsuitable feedstock for thermochemical conversion process. 319Breaking down of cellulose fibres in DIS by enzymes has been shown to not only add value to 320the feedstock, but also significantly reduce the water content and bulk of the sludge that has to 321be discarded (Steffen et al. 2017a). Williams (2017) has studied three different types of paper 322sludge for ethanol production and has reported that usage of enzymes and break down of 323cellulose has significantly reduced the water holding capacity and increased the bulk density 324of all the three types of paper sludge. This clearly indicates the advantage of using DIS as 325 feedstock for enzyme production as cellulase producing fungi are able to use cellulose present 326in the DIS as a substrate and reduce the bulk of sludge to be disposed. 
327Other important parameters anticipated to influence the growth and enzyme production 328(activity) of microorganisms on DIS include $\mathrm{pH}, \mathrm{C} / \mathrm{N}$ ratio as well as concentrations of 329bioavailable nutrients, ash and heavy metals (Table 1). The DIS used in this study has a dry 330 weight of $61.35 \%$ with $34.3 \%$ total organic carbon (TOC) and $1.48 \%$ nitrogen, indicating $\mathrm{C} / \mathrm{N}$ 331ratio of 23.3, which falls within the optimal range for maintaining optimal fungal growth and 332cellulose utilization (Wan and Li, 2012). This indicates that there is no additional requirement 333for a nitrogen source for fungal enzyme production using DIS as a substrate. This is 334advantageous in comparison to other cellulose-rich substrates, where nitrogen content and 335availability are among the main limitations affecting microbial degradation and enzyme 336production (Huang et al. 2017). Excess amounts of salts and nutrients used for process 337intensification and to maintain high cell mass no only increase the cost of the process, but can 338also be left unutilised or accumulated in the cells and are of environmental concern (Junker 3392010).

340Low concentrations of certain heavy metals are essential for transcription activation and 341 activity of certain oxidative enzymes, but excessive amounts may have inhibitory or toxic 342effects on some production strains (Lorenzo et al., 2006; Bhattacharya et al., 2013). The 343concentrations of heavy metals in DIS (Table 1) were lower than reported for some other 344paper mill sludges (Beauchamp et al., 2002; Abdullah et al., 2015) and did not exceed the 345concentrations typically found in non-contaminated soils (Tóth et al., 2016) which indicates 346that the risk of heavy metal inhibition on enzymes production is negligible with DIS as a 347substrate.

348

349Appreciable amounts of cellulose, low concentration of heavy metals, desirable C/N ratio 350(thus negating the need for supplementing additional nutrient requirements) indicate that DIS 351is a suitable feedstock for lignocellulolytic enzymes production. Enzyme production with DIS 
352as a substrate can be further improved by reducing the ash concentration and increasing the

353cellulose concentration in the substrate. Robus et al. (2016) has shown that washing the paper 354sludge can reduce the ash content in the paper sludge significantly. On the other hand, 355washing utilises large quantities of fresh water and hence is not considered suitable for 356sustainable and cleaner production. So, the fungal strains capable of growing under high $\mathrm{pH}$, 357high ash conditions and minimum nutrients should be targeted for enzymes production.

\subsection{Screening growth of selected strains on DIS}

361Results from our inititial screening, conducted to select fungal strains exhibiting the best 362growth on DIS, are presented in Fig. 2. Conceptually, these strains should be those producing 363enzyme mixtures that are most effective at breaking down the non-pretreated DIS with no or 364minimal supplementation of nutrients. Moreover, the strains exhibiting the best growth on 365DIS should be resistant to high pH of the substrate, chlorinated organic compounds or inks 366that are commonly found in this type of substrate (Monte et al., 2009). The growth of the 30 367selected fungal strains was monitored for 50 days and classified in different categories 368according to its ability / efficiency of growth on autoclaved (A-DIS) and non-pretreated (NA369DIS) medium (Fig. 2). While the autoclaved substrate supported the growth of 15 fungal 370strains, only 8 of these strains (all white rots), were able to grow on NA-DIS. However, all

371 except $P$. eryngii grew significantly better on the autoclaved substrate. This may be due to 372partial breakdown of cellulose fibres in DIS during hot steam treatment that may increase the 373bioavailability of nutrients, supporting larger spectrum of the strains (Zheng et al., 2014). In 374addition, the indigenous microbial community colonizing the NA-DIS may have exerted a 375 competitive exclusion effect that precluded growth of some of the less competitive fungal 376strains. Under such conditions, it is reasonable to conclude that the 8 strains able to grow on 
377the NA-DIS were able to successfully compete against the indigenous comunity for essential 378nutrients and resist the conditions established in the substrate.

379Pretreatment is considered as one of the major energy and cost intensive unit operation in 380lignocellulose biomass conversion and pressure vessels for sterilisation are one of the major 381capital investment cost in bioprocess industries (Brodeur et al., 2011). Steam sterilisation 382requires fresh water to generate steam and to cool the waste steam. The ability of the fungal 383strains to outgrow indigenous microbes colonizing DIS and to utilise untreated DIS is 384therefore a significant advantage in terms of energy and water usage. The majority of the 385strains that were able to grow on NA-DIS belonged to the genus Pleurotus which has 386previously been reported to have high tolerance to different types of environmental pollutants, 387such as heavy metals and polycylic aromatic compounds (Kapahi and Sachdeva, 2017). This 388has been associated with the ability to accumulate and immobilize (chelate) high levels of 389heavy metals (Yang et al., 2017). In addition, P. ostreatus and some white-rots producing 390ligninolytic enzymes have been shown to mineralize several persistent organic pollutants 391(POPs) to $\mathrm{CO}_{2}$ (Bezalel et al. 1996) and have therefore already been used for bioremediation 392of contaminated solid organic wastes (such as olive mill wastes) and soils (Kües, 2015). The 393potential and capacity of the strains selected in this work for bioremediation of DIS from 394different paper mills and pollutant loadings should further be studied.

395

\subsection{Screening enzyme activities of selected strains on DIS}

397Extracted secretomes of 10 strains exhibiting the most growth on A-DIS and ability to grow 398on NA-DIS were screened for target enzyme activities by plate assays. The latter reflected the 399inducibility of the genes encoding (ligno)cellulolytic enzymes by the elements in the 400 substrate, their translational efficiency as well as the stability and activity of the extract 401mixtures in given conditions (Lee, 2012). The SEEs of all the strains exhibited similar 
402xylanolytic activity, while endoglucanase activity was significantly higher in the four 403Pleurotus strains (PLAB, PP3, PLO4, PLOZ), C. purpereum (CHP4), H. ulmarius (HYUL1), 404P. ciliates (PC1) and G. lucidum (GAL5) than in the remaining two tested strains (Fig. 3). 405Laccase activity was only detected in seven of the tested strains and was most pronounced in 406two Pleurotus strains (PLAB, PP3) and H. ulmarius (HYUL1).

407As extracellular enzymes were separated from mycelia before testing, the enzymes 408performance must reflect their intrinsic stability (not associated with mycelial defense 409mechanisms, such as accumulation of toxic compounds or buffering) in the applied 410conditions, such as high $\mathrm{pH}$ and potentially inhibitory compounds.

411Enzyme performance at high pH values (8.6 in case of our substrate), typically associated 412with high amounts of mineral fillers present in DIS, is advantageous for many applications in 413the paper industry, as most of the current commercial cellulases perform best in weakly acidic 414conditions (pH 5-7)(Steffen et al, 2017a). Other factors that may affect stability and activity of 415enzymes produced on DIS are remaining organic pollutants or heavy metals (originating from 416inks). However, lignin-degrading oxidoreductases from different white rots have 417demonstrated not only resistance, but also the ability to degrade or transform broad range of 418organic pollutants (including pharmaceuticals) to less toxic species (Naghdi et al., 2018). 419Consequently, they have already been used to purify contaminated water or solid materials 420prior to release into an environment, as well as for bioremediation within different 421environments (Kües, 2015).

422 On the other hand, variable effects of different heavy metals on lignocellulolytic enzyme 423activities and stability were reported. While $\mathrm{Fe}^{2+}$ and $\mathrm{Cu}^{2+}$ mainly exerted inhibitory effects on 424fungal endoglucanases, exoglucanases, and $\beta$-glucosidases, the effects of other divalent ions 425 seems to be inconsistent among the enzymes secreted by different microorganisms (de Cassia 426Pereira et al., 2017). In contrary, most of the studies report positive effects of some heavy 
427metals (in particular $\mathrm{Cu}^{2+}$ and $\mathrm{Cd}^{2+}$ ) on oxidative enzymes, especially laccases (Yin et al., 4282017).

\section{9}

430

\subsection{Major proteins identified in $P$. ostreatus DIS-associated secretome}

432During their evolution, microorganisms have optimized the expression of genes encoding 433lignocellulolytic enzymes by sensing and responding to the composition of the available 434substrate in most efficient ways (Fernández-Fueyo et al., 2016). Studying the composition of 435enzyme consortia secreted on different target substrates is therefore useful for understanding 436the mechanisms of their degradation and for the successful design and production of enzyme 437cocktails optimized for specific industrial processes (Vodovnik and Marinšek Logar, 2010).

438Our study revealed six most abundant proteins in the secretome of P. ostreatus PLAB likely 439involved in the degradation of DIS (Table 2, Suppl. 4, 5). Among these were two laccase 440isoenzymes with the theoretical Mw of 57.4 and 56.7. Two enzymes with ABTS-oxidasing 441 activity were also confirmed by zymogram approach (Suppl. 6C) - however, their activity 442was only detected following native separation conditions and was irreversibly lost if the 443samples were pretreated by SDS. SDS-associated inhibition of isolated Pleurotus sp. laccase 444has also been observed by More et al. (2011). Despite their sensitivity to certain compounds, 445laccases have huge biotechnological potential in the pulp and textile industry as well as for 446beverage processing, organic synthesis, the manufacture of biodevices and the detoxification 447of pollutants (Cañas and Camarero, 2010).

448Feruloyl esterase, a hydrolase catalyzing the cleavage of bonds between plant cell wall 449polysaccharide and phenolic acid, and bilirubin oxidase, an oxidoreductase from cupredoxin 450family, were also identified among the secreted proteins. Both of these enzymes are 
451considered promising tools for different biotechnological applications. While feruloyl 452esterases may be used for bio-refining of lignocellulosic material for the recovery and 453purification of ferulic acid and related hydroxycinnamic acids ubiquitously found in the plant 454cell wall (Gopalan et al., 2015), bilirubin oxidases have promising applications in dye effluent 455decolorization (Liu et al., 2009) and in biofuel cells (Durand, 2012).

456A cellobiohydrolase (enzyme releasing cellobiose from the non-reducing ends of cellulose 457chains) was also identified among the major P.ostreatus proteins produced on DIS (Table 2). 458In addition, six other cellulases were also detected in zymograms (Suppl. 6A). The Mw range 459of the three enzymes with the most pronounced activites correlated with four theoretically 460predicted Mw of P. ostreatus cellulases listed in the NCBI Protein database (Suppl. 3A). In 461 addition, three bands revealing enzymes with xylanolytic activity correlating with $P$. ostreatus 462putative xylanases KDQ24406, KDQ24407 and KDQ33930 were visualized (Suppl. 3B). 463Another fainter degradation band with a Mw between 45 and $50 \mathrm{kDa}$ did not correlate with 464any of the predicted gene products indicating it may be a post-translationaly modified 465enzyme. Interestingly, glycoside hydrolases detected in the zymograms proved resistant to 466rigorous pre-separation treatment (heating in SDS-buffer), as their activities were recovered 467after the renaturation steps. Similar stability has previously been reported with some other 468extracellular glycoside hydrolases, i.e. from anaerobic cellulolytic bacteria (Vodovnik and 469Marinšek Logar, 2012; Hatefi et al., 2017).

470In addition to proteins traditionally involved in lignocellulose degradation, peptidase 1 was 471also detected among proteins of $P$. ostreatus PLAB produced on DIS. Fungal proteases 472typically act as virulence factors (Monod et al., 2002), but the results of current research 473indicate that they may also play a role in debranching polysaccharide linkages within plant 474cell wall proteins and thus providing access to proteins as sources of carbon and nitrogen. The 475low content of available nitrogen that is typical for the majority of lignocellulosic substrates 
476implies that the expression of specific proteases could be advantageous for releasing nitrogen 477 from organic matter such as that contained in plant material or associated microbial biomass 478(Sato et al., 2007). High expression of proteases and peptidases was also detected in 479Aspergillus fumigatus (Adav et al., 2015), Trichoderma reesei (Borin et al., 2015), 480Pycnoporus coccineus (Couturier et al., 2015) and Pleurotus ostreatus PC9 (Fernández-Fueyo 481et al., 2016) secretomes produced on different lignocellulosic biomasses. The enzyme 482identified in our study belongs to family S8 peptidases (subtilase clan), which are typically 483thermostable alkaline peptidases, that may be suitable for different biotechnological 484applications (especially detergent industry) (Apolinar-Hernandéz et al., 2016). 485Implementation of enzyme technologies in paper, textile and biofuel industry is a promising 486means toward cleaner industrial production. The results of several studies show that 487implementing enzymatic processes in place of conventional processes generally results in a 488reduced contribution to global warming and also a reduced contribution to acidification, 489eutrophication, photochemical ozone formation and energy use (Jeganathan and Nielsen, 4902013).

491

\subsection{Enzymes production from DIS}

493Due to its efficient growth on pretreated as well as non-pretreated DIS and its highest 494screened enzyme activities, $P$. ostreatus PLAB was chosen as the most promising candidate 495for further quantitative analysis of enzyme production on target substrate. Target enzyme 496activities detected in enzyme extracts at different fermentation times are shown Fig. 4. The 497endoglucanase activities recovered from overgrown substrate consistently remained between $4981.5-3.0 \mu \mathrm{mol} / \mathrm{min} / \mathrm{g}_{\mathrm{DIs}}$ throughout all the growth stages. This is higher than previously 499reported for $P$. ostreatus during SSF on coffee pulp and similar as in cultures grown on a 500mixture of supplemented wheat and rice straw as a substrate (Kurt and Buyukalaca, 2010). On 
501the other hand, Khalil et al. (2011) reported higher endoglucanase activity after 12 days of 502SSF on rice straw (Suppl. 2A).

503Xylanase activities in the extracts varied from $1.5-4.0 \mu \mathrm{mol} / \mathrm{min} / \mathrm{g}$. These activities are lower 504than detected in extracts from mycelia grown on corn and wheat bran, tomato waste or a 505mixture of Fagus sylvatica leaves and wheat straw as substrates (Suppl. 2B). This may be 506associated with the lack of inducing compounds originating from the substrate, since natural 507(ligno)cellulosic substrates usually contain a substantial portion of hemicelluloses (20-30\%), 508while its amounts in paper sludge remain very low due to their removal during the pulping 509process, with only 3.7\% hemicellulose remaining in the DIS used in our study. The 510mechanisms of regulation and substrate-associated expression patterns of genes encoding 511hemicellulases in P. ostreatus are not yet well understood. However, research on related fungi 512confirmed their coordinated regulation is associated with molecular signals reflecting 513substrate composition (Cai et al., 2017).

514The changes in endoglucanase activity and xylanase activity did not correlate with total 515protein concentration time-wise, since enzyme production apparently peaked in earlier 516fermentation (growth) phases (maximal endoglucanase and xylanase activity was detected at 51723 days of growth), which is in accordance with the fact that the production of these enzymes 518is an essential predisposition for nutrient acquirement from the substrate (Fig. 4A).

519In contrast to endoglucanase and xylanase, laccase activity in P. ostreatus DIS-induced 520secretome strongly correlated with total proteins (reflecting growth of fungal mycelia) and 521 peaked between 30 and 44 days of incubation, achieving its highest average activity of $49 \pm 5$ $522 \mu \mathrm{mol} \mathrm{ABTS}^{*}+/ \mathrm{min} / \mathrm{g}$ Dis after 37 days and declining thereafter (Fig. 4B). Laccase activity 523detected in enzyme extracts from $P$. ostreatus on DIS were significantly (10-30 times) higher 524than reported for other lignocellulose substrates, such as lyophilized wheat straw, wheat bran 
525and spent brewery grains (Suppl. 2C). Since DIS contains lower amounts of lignin than

526reported for the aforementioned substrates (6.2\% in our study), high laccase activity in

527P. ostreatus PLAB secretome may be associated with other inducing compounds present in

528this substrate. In addition to nitrogen source and concentration, heavy metal ions and certain

529phenolic and (poly)aromatic compounds with structural similarities to lignin have previously

530been shown to positively regulate expression of laccases (Zhuo et al., 2017) and other

531ligninolytic enzymes (Zhang et al., 2016). The deinking sludge used in our study contained

532significant amounts of copper (64.99 mg/kg dry content), which has been reported to act as a

533strong transcriptional inducer and activity promotor of laccases (Lorenzo et al., 2006) and

534lignin-modifying peroxidases with several white rots (Zheng et al., 2017).

535Due to possible effects of substrate composition on enzyme production, it is important that the

536substrates from different paper milly be characterized so as to support optimization of

537amounts and types of enzymes produced. If the production of specific type of enzymes would

538be an objective, the substrate composition should be adjusted by adding relevant inducers (i.e. 539xylan for increasing xylanase production or specific heavy metals to increase ligninase 540production).

\section{1}

\subsection{Advantages of enzyme production from DIS via SSF}

543The advantage of SSF processes for enzyme production is lower water consumption and 544hence relatively less energy is required to concentrate the target enzymes (Yoon et al., 2014). 545DIS produced in current practice is a waste stream with zero value, substantial disposal costs 546and no proper environmentaly friendly disposal method, therefore repurposing it as a 547 feedstock not only reduces the waste to be disposed from tissue printed recycle mills but also 548adds revenue to the industry (Gottomukkala, 2016). Laccases are enzymes with tremendous 549application potential in paper and pulp industry for delignification and brightening of pulp, as 
550well as in bioremediation of toxic compounds released from the industry (Virk et al., 2012).

551Endoglucanases and small quantities of xylanases produced may be used for conversion of 552cellulosic rich feedstock to value added chemicals and hence can be used within the paper 553industry to convert paper sludge or undigested residues of enzyme fermentation to fuel and 554chemicals (Gottomukkala et al., 2016). This study has proven that DIS is a potential feedstock 555 for production of lignocellulytic enzymes and induces laccase production at high 556concentrations. Moreover, this study has shown that DIS as a feedstock needs no additional 557supplementation of nutrients which thus reduces the burden of waste on the environment. 558Well known bioprocess like direct ethanol production from paper sludge requires high solids 559loading to achieve threshold ethanol concentrations of $40 \mathrm{~g} / \mathrm{L}$ (Robus et al., 2016). Viscosity 560of paper sludge at such high solids loading is a major limitation and high ash content of the 561sludge significantly influences the final ethanol concentration (Gottumukkala et al., 2016). 562Hence, the suggested technology, to use Pleurotus ostreatus for enzymes production with DIS 563by SSF without any supplementation, pretreatment and sterilization requirement, may 564therefore be a suitable cost-effective alternative for paper sludge valorisation to ethanol. 565However, to increase the enzyme concentration and yields further experiments testing co566 fermentation with additional nitrogen rich waste streams need to be explored in the future. 567This approach would help in valorisation and treatement of two different waste streams. In 568addition, the effects of the variations in the DIS composition on the ratios of the different 569types of the produced enzymes should be explored. The residues from the SSF of DIS should 570be investigated and potentially used for biogas production (Steffen et al., 2017b). Further 571 studies are warranted, to optimize the production, economic feasibility and environmental 572 benefits of this technology.

\section{3}




\section{Conclusions}

576Enzymes production for lignocellulose degradation is currently a cost intensive process and 577utilises fresh water and nutrients which in turn results in additional waste stream generation. If 578combined with efficient and robust microbial enzyme producers, lignocellulosic wastes have 579an enormous potential for developing a sustainable chemical and energy industry as the most 580inexpensive feedstock among all the renewable resources. The results of our study have 581shown that the deinking paper sludge represents a suitable feedstock for the production of 582lignocelulolytic enzymes by selected Pleurotus strains. The selected strains exhibited 583outstanding ability to transform untreated and unsterilized DIS to a mixture of alkali-stable 584enzymes (mainly with endoglucanase, xyalanase and particulary high laccase activities). 585Production of lignocellulases from unsterilized DIS by SSF should therefore be considered at 586an industrial level to add value to the major waste stream of paper industry by reducing waste 587disposal, costs associated with the disposal of wastes to landfill sites and by yielding high 588value enzymes suitable for application in biorefinery, paper and pulp, detergent and textile 589industries. Further research should be done to analyse (anticipated positive) effects of the 590process on the levels and bioavailability of environmental pollutants potentially present in 591DIS. In addition, the enzymes production should be further optimized and process conditions 592fine-tuned to increase the yield and productivity of individual enzymes and the cocktail. 593Major advantages of this process such as less water usage, less energy usage and reduced 594waste disposal should be studied in detail for its energy, economic and environment benefits.

595

\section{Acknowledgements}

597This research was supported by Slovenian Research Agency (ARRS). We thank prof. R.

598Marinšek Logar for helpful advice, Dr. T. Kranjc for help with data management, N. Vrhovnik 
599and G. Lavrič for technical help with preliminary growth experiments and dr. J. Burkeljca for 600help with graphics.

601

\section{References}

603Abdullah, R., Ishak, C.F., Kadir, W.R., Bakar, R.A., 2015. Characterization and feasibility

604assessment of recycled paper mill sludges for land application in relation to the environment. 605Int. J. Environ. Res. Public Health 12(8), 9314-9329. https://doi.org/10.3390/ijerph120809314

606Adav, S.S., Ravindran, A., Sze, S.K., 2015. Quantitative proteomic study of Aspergillus 607Fumigatus secretome revealed deamidation of secretory enzymes. J. Proteomics 119, 154608168. https://doi.org/10.1016/j.jprot.2015.02.007

609Apolinar-Hernandez, M.M., Pena-Ramirez, Y.J., Perez-Rueda, E., Canto-Canche, B.B., De 610Los Santos-Briones, C., O’Connor-Sanchez, A., 2016. Identification and in silico 611characterization of two novel genes encoding peptidases S8 found by functional screening in a 612metagenomic library of Yucatan underground water. Gene 593(1), 154-161.

\section{3https://doi.org/10.1016/j.gene.2016.08.009}

614Bajpai P., 2013. Recycling and Deinking of Recovered Paper. Recycling and Deinking of 615Recovered Paper. First ed. Elsevier.

616Beauchamp, C.J., Charest, M.H., Gosselin, A., 2002. Examination of environmental quality of 617raw and composting de-inking paper sludge. Chemosphere 46(6), 887-895.

\section{8https://doi.org/10.1016/S0045-6535(01)00134-5}

619Bhattacharya, S., Das, A., Prashanthi, K., Palaniswamy, M., Angayarkanni, J., 2013. 620Mycoremediation of Benzo[a]pyrene by Pleurotus ostreatus in the presence of heavy metals 621and mediators. 3 Biotech. 4(2), 205-211. https://doi.org/10.1007/s13205-013-0148-y 
622Boshoff, S., Gottumukkala, L.D., van Rensburg, E., Görgens, J., 2016. Paper sludge (PS) to

623bioethanol: Evaluation of virgin and recycle mill sludge for low enzyme, high-solids

624fermentation. Bioresour. Technol. 203, 103-111.

\section{5https://doi.org/10.1016/j.biortech.2015.12.028}

626Brodeur, G., Yau, E., Badal, K., Collier, J., Ramachandran, K.B., Ramakrishnan, S., 2011.

627Chemical and physicochemical pretreatment of lignocellulosic biomass: A review. Enzyme 628Res. 2011, 1-17. https://doi.org/10.4061/2011/787532

629Cai, Y., Gong, Y., Liu, W., Hu, Y., Chen, L., Yan, L., Zhou, Y., Bian, Y., 2017. Comparative 630secretomic analysis of lignocellulose degradation by Lentinula edodes grown on

631microcrystalline cellulose, lignosulfonate and glucose. J. Proteomics 163, 92-101.

632https://doi.org/10.1016/j.jprot.2017.04.023

633Cañas, A.I., Camarero, S., 2010. Laccases and their natural mediators: Biotechnological tools 634for sustainable eco-friendly processes. Biotechnol. Adv. 28(6), 694-705.

635https://doi.org/10.1016/j.biotechadv.2010.05.002

636Castanera, R., Pérez, G., Omarini, A., Alfaro, M., Pisabarro, A.G., Faraco, V., Amore, A., 637Ramírez, L., 2012. Transcriptional and enzymatic profiling of Pleurotus ostreatus laccase 638genes in submerged and solid-state fermentation cultures. Appl Env. Microbiol 78, 40376394045. https://doi.org/10.1128/AEM.07880-11

640Childs, B.R.E., Bardsley, W.G., 1975. The Steady-State Kinetics of Peroxidase with 2,2'641Azino-di-(3-ethylbenzthiazoline- 6-sulphonic acid) as Chromogen. Biochem. J. 145, 93-103 642https://doi.org/10.1042/bj1450093

643Couturier, M., Navarro, D., Chevret, D., Henrissat, B., Piumi, F., Ruiz-Dueñas, F.J., Martinez, 644A.T., Grigoriev, I. V., Riley, R., Lipzen, A., Berrin, J.-G., Master, E.R., Rosso, M.-N., 2015. 
645Enhanced degradation of softwood versus hardwood by the white-rot fungus Pycnoporus 646coccineus. Biotechnol. Biofuels. 8(216), 1-16. https://doi.org/10.1186/s13068-015-0407-8

647Dahl O. 2008. Papermaking Science and Technology: Environmental Management and 648Control. Second Ed. Finnish Paper Engineers' Association, Helsinki.

649Deviatkin, I., Kapustina, V., Vasilieva, E., Isyanov, L., Horttanainen, M., 2016. Comparative 650life cycle assessment of deinking sludge utilization alternatives. J. Clean. Prod. 112, 32326513243. https://doi.org/10.1016/j.jclepro.2015.10.022

652Durand, F., Kjaergaard, C.H., Suraniti, E., Gounel, S., Hadt, R.G., Solomon, E.I., Mano, N., 6532012. Bilirubin oxidase from Bacillus pumilus: A promising enzyme for the elaboration of 654efficient cathodes in biofuel cells. Biosens. Bioelectron. 35, 140-146.

\section{5https://doi.org/10.1016/j.bios.2012.02.033}

656Dyballa, N., Metzger, S., 2009. Fast and Sensitive Colloidal Coomassie G-250 Staining for 657Proteins in Polyacrylamide Gels. J. Vis. Exp. 3, 2-5. https://doi.org/10.3791/1431

658Elisashvili, V., Penninckx, M., Kachlishvili, E., Tsiklauri, N., Metreveli, E., Kharziani, T., 659Kvesitadze, G., 2008. Lentinus edodes and Pleurotus species lignocellulolytic enzymes 660activity in submerged and solid-state fermentation of lignocellulosic wastes of different 661composition. Bioresour. Technol. 99, 457-462. https://doi.org/10.1016/j.biortech.2007.01.011 662Ellilä, S., Fonseca, L., Uchima, C., Cota, J., Goldman, G.H., Saloheimo, M., Sacon, V., Siika663Aho, M., 2017. Development of a low-cost cellulase production process using Trichoderma 664reesei for Brazilian biorefineries. Biotechnol. Biofuels. 10 (30), 1-17.

\section{5https://doi.org/10.1186/s13068-017-0717-0}

666Fernández-Fueyo, E., Ruiz-Dueñas, F.J., López-Lucendo, M.F., Pérez-Boada, M., Rencoret, 667J., Gutiérrez, A., Pisabarro, A.G., Ramírez, L., Martínez, A.T., 2016. A secretomic view of 
668woody and nonwoody lignocellulose degradation by Pleurotus ostreatus. Biotechnol. 669Biofuels. 9(49), 1-18. https://doi.org/10.1186/s13068-016-0462-9

670Fukushima, R.S., Kerley, M.S., Ramos, M.H., Porter, J.H., Kallenbach, R.L., 2015.

671Comparison of acetyl bromide lignin with acid detergent lignin and Klason lignin and 672correlation with in vitro forage degradability. Anim. Feed Sci. Technol. 201, 25-37.

\section{3https://doi.org/10.1016/j.anifeedsci.2014.12.007}

674Furlan de Jesus, J.P., Sain, M., Jeng, R., Negrão, D.R., Leão, A.L., Nogueira de Andrade, 675M.C., Almeida Minhoni, M.T. de, 2015. Potential application of Ganoderma lucidum in solid 676state fermentation of primary sludge and wheat straw. BioResources 10, 3197-3209.

\section{7https://doi.org/10.15376/biores.10.2.3197-3209}

678Garajova, S., Mathieu, Y., Beccia, M.R., Bennati-Granier, C., Biaso, F., Fanuel, M., Ropartz, 679D., Guigliarelli, B., Record, E., Rogniaux, H., Henrissat, B., Berrin, J.-G., 2016. Single680domain flavoenzymes trigger lytic polysaccharide monooxygenases for oxidative degradation 681of cellulose. Sci. Rep. 6, 28276. https://doi.org/10.1038/srep28276

682Gasteiger E, Hoogland C, Gattiker A, Duvaud S, Wilkins MR, Appel RD, Bairoch A., 2009. 683Protein Identification and Analysis Tools on the ExPASy Server. In: John M. Walker (Ed): 684The Proteomics Protocols Handbook, Humana Press, New Jersey, pp. 571-607

685Gopalan, N., Rodríguez-Duran, L.V., Saucedo-Castaneda, G., Nampoothiri, K.M., 2015. 686Review on technological and scientific aspects of feruloyl esterases: A versatile enzyme for 687biorefining of biomass. Bioresour. Technol. 193, 534-544.

688https://doi.org/10.1016/j.biortech.2015.06.117

689Gottumukkala, L.D., Haigh, K., Collard, F.X., van Rensburg, E., Görgens, J., 2016. 6900pportunities and prospects of biorefinery-based valorisation of pulp and paper sludge. 691Bioresour. Technol. 215, 37-49. https://doi.org/10.1016/j.biortech.2016.04.015 
692Gregori, A., Švagelj, M., Pahor, B., Berovič, M., Pohleven, F., 2008. The use of spent brewery 693grains for Pleurotus ostreatus cultivation and enzyme production. N. Biotechnol. 25, 157-161. 694https://doi.org/10.1016/j.nbt.2008.08.003

695Hatefi, A., Makhdoumi, A., Asoodeh, A., Mirshamsi, O., 2017. Characterization of a bi696functional cellulase produced by a gut bacterial resident of Rosaceae branch borer beetle, 697Osphranteria coerulescens (Coleoptera: Cerambycidae). Int. J. Biol. Macromol. 103, 158-164. 698https://doi.org/10.1016/j.ijbiomac.2017.05.042

699Heux, S., Meynial-Salles, I., O’Donohue, M.J., Dumon, C., 2015. White biotechnology: State 700of the art strategies for the development of biocatalysts for biorefining. Biotechnol. Adv. 33, 7011653-1670. https://doi.org/10.1016/j.biotechadv.2015.08.004

702Heyer, R., Kohrs, F., Benndorf, D., Rapp, E., Kausmann, R., Heiermann, M., Klocke, M., 703Reichl, U., 2013. Metaproteome analysis of the microbial communities in agricultural biogas 704plants. N. Biotechnol. 30, 614-622. https://doi.org/10.1016/j.nbt.2013.01.002

705Hidayati N, Surtiningsih T, Matuzahroh N. 2014. Removal of heavy metals Pb, Zn and Cu 706from sludge waste of paper industries using biosurfactant. J Bioremediation Biodegrad. 5: 707255. https://doi:10.4172/2155-6199.1000255

708Huang, S., Huang, D., Wu, Q., Hou, M., Tang, X., Zhou, J., 2017. The Effects of 709Environmental C/N on the Activities of Lignin-degrading Enzymes Produced by 710Phanerochaete chrysosporium. Pedosphere. https://doi.org/10.1016/S1002-0160(17)60391-6

711Humbird, D., Davis, R., Tao, L., Kinchin, C., Hsu, D., Aden, A., 2011. Process Design and 712Economics for Biochemical Conversion of Lignocellulosic Biomass to Ethanol. Renew. 713Energy. NREL/TP-5100-47764. https://doi.org/10.2172/1013269 
714Iandolo, D., Piscitelli, A., Sannia, G., Faraco, V., 2011. Enzyme production by solid substrate 715fermentation of pleurotus ostreatus and trametes versicolor on tomato pomace. Appl.

716Biochem. Biotechnol. 163(1), 40-51. https://doi.org/10.1007/s12010-010-9014-0

717Jegannathan, K.R., Nielsen, P.H., 2013. Environmental assessment of enzyme use in industrial 718production - a literature review. J. Clean. Prod. 42, 228-240.

\section{9https://doi.org/10.1016/J.JCLEPRO.2012.11.005}

720Junker, B., 2010. Minimizing the environmental footprint of bioprocesses - Part 2: Evaluation 721 of wastewater, electricity, and air emissions. Bioprocess Int. 2010, 62-70

722Kang, L., Wang, W., Lee, Y.Y., 2010. Bioconversion of kraft paper mill sludges to ethanol by 723SSF and SSCF. Appl. Biochem. Biotechnol. 161, 53-66. https://doi.org/10.1007/s12010-009724ㅁ893-4

725Kapahi, M., Sachdeva, S., 2017. Mycoremediation potential of Pleurotus species for heavy 726metals: a review. Biores Bioproc. 2017; 4(1), 32. https://doi.org/10.1186/s40643-017-0162-8

727Khalil, M.I., Hoque, M.M., Basunia, M.A., Alam, N., Khan, M.A., 2011. Production of 728cellulase by Pleurotus ostreatus and Pleurotus sajor-caju in solid state fermentation of 729lignocellulosic biomass. Turkish J. Agric. For. 35, 333-341. https://doi.org/10.3906/tar-1002$730 \underline{684}$

731Knežević, A., Milovanović, I., Stajić, M., Lončar, N., Brčeski, I., Vukojević, J., Ćilerdžić, J., 7322013. Lignin degradation by selected fungal species. Bioresour. Technol. 138, 117-123.

733https://doi.org/10.1016/j.biortech.2013.03.182

734Kurschner, K., Hoffer, A. 1993. Cellulose and cellulose derivative. Fresenius J Anal Chem. 73592, 145-154. 
736Kurt, S., Buyukalaca, S., 2010. Yield performances and changes in enzyme activities of 737Pleurotus spp. (P. ostreatus and P. sajor-caju) cultivated on different agricultural wastes. 738Bioresour. Technol. 101, 3164-3169. https://doi.org/10.1016/j.biortech.2009.12.011

739Kües, U., 2015. Fungal enzymes for environmental management. Curr. Opin. Biotechnol. 33, 740268-278. https://doi.org/10.1016/j.copbio.2015.03.006

741Laemmli, U.K., 1970. Cleavage of structural proteins during the assembly of the head of 742bacteriophage T4. Nature 227, 680-685. https://doi.org/10.1038/227680a0

743Lee, J.W., 2012. Advanced biofuels and bioproducts, Advanced Biofuels and Bioproducts. 744Springer, New York, pp. 1122. https://doi.org/10.1007/978-1-4614-3348-4

745Lever, M., 1977. Carbohydrate determination with 4-hydroxybenzoic acid hydrazide 746(PAHBAH): effect of bismuth on the reaction. Anal. Biochem. 81, 21-27.

747Liguori, R., Faraco, V., 2016. Biological processes for advancing lignocellulosic waste 748biorefinery by advocating circular economy. Bioresour. Technol. 215, 13-20.

749https://doi.org/10.1016/j.biortech.2016.04.054

750Likon, M., Saarela, J., 2012. The Conversion of Paper Mill Sludge into Absorbent for Oil 751Spill Sanitation - The Life Cycle Assessment. Macromol. Symp. 320, 50-56.

752https://doi.org/10.1002/masy.201251006

753Likon, M., Trebše, P., 2012. Recent advances in paper mill sludge management, in: Show KY, 754Guo X (Eds), Industrial Waste. InTech Open, London. pp. 73-90.

755https://doi.org/10.5772/37043

756Liu, Y., Huang, J., Zhang, X., 2009. Decolorization and biodegradation of remazol brilliant 757blue R by bilirubin oxidase. J. Biosci. Bioeng. 108, 496-500.

758https://doi.org/10.1016/j.jbiosc.2009.06.001 
759Lorenzo, M., Moldes, D., Sanromán, M.Á., 2006. Effect of heavy metals on the production of 760several laccase isoenzymes by Trametes versicolor and on their ability to decolourise dyes. 761Chemosphere 63, 912-917.

762https://doi.org/http://dx.doi.org/10.1016/j.chemosphere.2005.09.046

763Lowry, O.H., Rosebrough, N.J., Farr, A.L., Randall, R.J. 1951. Protein measurement with the 764Folin phenol reagent. J Biol Chem. 193, 265-275.

765Machrafi, Y., Chalifour, F.-P., Wamegni, J., Beauchamp, C.J., 2008. Short-term effects of 766deinking paper sludge on the dynamics of soil carbon, nitrogen, and phenolic compounds. J. 767Agric. Food Chem. 56, 11399-11406. https://doi.org/10.1021/jf801443a

768Manavalan, T., Manavalan, A., Heese, K., 2015. Characterization of Lignocellulolytic 769Enzymes from White-Rot Fungi. Curr. Microbiol. 70, 485-498.

770https://doi.org/10.1007/s00284-014-0743-0

771Meng, X., Ragauskas, A.J., 2014. Recent advances in understanding the role of cellulose 772accessibility in enzymatic hydrolysis of lignocellulosic substrates. Curr. Opin. Biotechnol. 27, 773150-8. https://doi.org/10.1016/j.copbio.2014.01.014

774Mohan, S.V., Butti, S.K., Amulya, K., Dahiya, S., Modestra, J.A., 2016. Waste Biorefinery: A 775New Paradigm for a Sustainable Bioelectro Economy. Trends Biotechnol. 34, 852-855.

776https://doi.org/10.1016/j.tibtech.2016.06.006

777

778Monod, M., Capoccia, S., Léchenne, B., Zaugg, C., Holdom, M., Jousson, O., 2002. Secreted 779proteases from pathogenic fungi. Int. J. Med. Microbiol. 292, 405-419.

780https://doi.org/10.1078/1438-4221-00223 
781Monte, M.C., Fuente, E., Blanco, A., Negro, C., 2009. Waste management from pulp and 782paper production in the European Union. Waste Manag. 29, 293-308.

\section{3https://doi.org/10.1016/j.wasman.2008.02.002}

784More, S.S., Renuka, P.S., Pruthvi, K., Swetha, M., Malini, S., Veena, S.M., 2011. Isolation, 785purification, and characterization of fungal laccase from Pleurotus sp. Enzyme Res. 2011, 1-7.

\section{6https://doi.org/10.4061/2011/248735}

787Naghdi, M., Taheran, M., Brar, S.K., Kermanshahi-pour, A., Verma, M., Surampalli, R.Y., 7882018. Removal of pharmaceutical compounds in water and wastewater using fungal 789oxidoreductase enzymes. Environ. Pollut. 234, 190-213.

\section{0https://doi.org/10.1016/J.ENVPOL.2017.11.060}

791Pereira, J., Giese, E.C., de Souza, M.M., Gomes, A.C., Perrone, O.M., Boscolo, P., Roberto da 792Silva, Gomes, E., Bocchini Martins, E., 2017. Effect of Metal Ions, Chemical Agents and 793Organic Compounds on Lignocellulolytic Enzymes Activities, in: Şentürk (Ed.), Enzyme 794Inhibitors and Activators. InTech Open, London. https://doi.org/10.5772/65934.

795Pointner, M., Kuttner, P., Obrlik, T., Jäger, A., Kahr, H., 2014. Composition of corncobs as a 796substrate for fermentation of biofuels. Agron. Res.12(2), 391-396.

797Prasetyo, J., Park, E.Y., 2013. Waste paper sludge as a potential biomass for bio-ethanol 798production. Korean J. Chem. Eng.30, 253-261.

799Quevillon, E., Silventoinen, V., Pillai, S., Harte, N., Mulder, N., Apweiler, R., Lopez, R., 8002005. InterProScan: Protein domains identifier. Nucleic Acids Res. 33, W116-120.

801https://doi.org/10.1093/nar/gki442

802Robus, C.L.L., Gottumukkala, L.D., van Rensburg, E., Görgens, J.F., 2016. Feasible process 803development and techno-economic evaluation of paper sludge to bioethanol conversion: 
804South African paper mills scenario. Renew. Energy, 92, 333-345.

805https://doi.org/10.1016/j.renene.2016.02.017

806Sato, S., Liu, F., Koc, H., Tien, M., 2007. Expression analysis of extracellular proteins from 807Phanerochaete chrysosporium grown on different liquid and solid substrates. Microbiology808Sgm 153, 3023-3033. https://doi.org/10.1099/mic.0.2006/000513-0

809Schomburg, I., Chang, A., Ebeling, C., Gremse, M., Heldt, C., Huhn, G., Schomburg, D., 8102004. BRENDA, the enzyme database: updates and major new developments. Nucleic Acids 811Res. 2, D431-D433. https://doi.org/10.1093/nar/gkh081

812Schweikl, H., Klein, U., Schindlbeck, M., Wieczorek, H., 1989. A vacuolar-type ATPase, 813partially purified from potassium transporting plasma membranes of tobacco hornworm 814midgut. J. Biol. Chem. 264(19), 11136-11142.

815Steffen, F., Janzon, R., Saake, B., 2017a. Enzymatic treatment of deinking sludge - effect on 816fibre and drainage properties. Environ. Technol. 2017, 1-17.

817https://doi.org/10.1080/09593330.2017.1365948

818Steffen, F., Janzon, R., Wenig, F., Saake, B., 2017b. Valorization of waste streams from 819deinked pulp mills through anaerobic digestion of deinking sludge. BioResources,12, 45478204566. https://doi.org/10.15376/biores.12.3.4547-4566

821Teather, R.M., Wood, P.J., 1982. Use of Congo red-polysaccharide interactions in enumeration 822 and characterization of cellulolytic bacteria from the bovine rumen. Appl. Environ. Microbiol. 82343, 777-780. https://doi.org/0099-2240/82/040777-04\$02.00/0

824Tóth, G., Hermann, T., Da Silva, M.R., Montanarella, L., 2016. Heavy metals in agricultural 825soils of the European Union with implications for food safety. Environ. Int. 88, 299-309. 826https://doi.org/10.1016/j.envint.2015.12.017 
827Velázquez-Cedeño, M.A., Mata, G., Savoie, J.M., 2002. Waste-reducing cultivation of 828Pleurotus ostreatus and Pleurotus pulmonarius on coffee pulp: Changes in the production of 829some lignocellulolytic enzymes. World J. Microbiol. Biotechnol. 18, 201-207.

\section{0https://doi.org/10.1023/A:1014999616381}

831Virk, A.P., Sharma, P., Capalash, N., 2012. Use of laccase in pulp and paper industry. 832Biotechnol. Prog. 28(1), 21-32. https://doi.org/10.1002/btpr.727

833Vodovnik, M., Logar, R.M., 2012. Expression patterns of Ruminococcus flavefaciens 007S 834cellulases as revealed by zymogram approach. Folia Microbiol. 57, 367-370.

\section{5https://doi.org/10.1007/s12223-012-0144-3}

836Vodovnik, M., Logar, R.M., 2010. Cellulosomes - Promising supramolecular machines of 837anaerobic cellulolytic microorganisms. Acta Chim. Slov. 57(4), 767-774.

838Vodovnik, M., Duncan, S.H., Reid, M.D., Cantlay, L., Turner, K., Parkhill, J., Lamed, R., 839Yeoman, C.J., Miller, M.E.B., White, B.A., Bayer, E.A., Marinšek-Logar, R., Flint, H.J., 8402013. Expression of Cellulosome Components and Type IV Pili within the Extracellular 841Proteome of Ruminococcus flavefaciens 007. PLoS One 8(6), 1-11.

\section{2https://doi.org/10.1371/journal.pone.0065333}

843Wan, C., Li, Y., 2012. Fungal pretreatment of lignocellulosic biomass. Biotechnol. Adv. 30, 8441447-1457. https://doi.org/10.1016/j.biotechadv.2012.03.003

845Wheeler, D.L., Church, D.M., Lash, A.E., Leipe, D.D., Madden, T.L., Pontius, J.U., Schuler, 846G.D., Schriml, L.M., Tatusova, T.A., Wagner, L., Rapp, B.A., 2002. Database resources of the 847National Center for Biotechnology Information: 2002 update. Nucleic Acids Res. 30(1), 1384816. https://doi.org/10.1093/nar/gkh073 
849Williams A. The production of bioethanol and biogas from paper sludge. Chemical 850engineering, Stellenbosch University. 2017 (Masters’ thesis).

851Willis, J.D., Klingeman, W.E., Oppert, C., Oppert, B., Jurat-Fuentes, J.L., 2010.

852Characterization of cellulolytic activity from digestive fluids of Dissosteira carolina

853(Orthoptera: Acrididae). Comp. Biochem. Physiol. Part B Biochem. Mol. Biol. 157, 267-272. 854https://doi.org/10.1016/j.cbpb.2010.06.012

855Wise, L.E., Karl, H.L. 1962. Cellulose and hemicellulose. In: Earl, L.C. (Ed.) Pulp and paper 856science and technology. vol. 1. McGraw Hill Book Co., New York, pp.54-73.

857Yang, S., Sun, X., Shen, Y., Chang, C., Guo, E., La, G., Zhao, Y., Li, X., 2017. Tolerance and 858Removal Mechanisms of Heavy Metals by Fungus Pleurotus ostreatus Haas. Water, Air, Soil 859Pollut. 228, 130-139. https://doi.org/10.1007/s11270-016-3170-y

860

861 Yoon, L.W., Ang, T.N., Ngoh, G.C., Chua, A.S.M., 2014. Fungal solid-state fermentation and 862various methods of enhancement in cellulase production. Biomass and Bioenergy. 67, 319863338. https://doi.org/10.1016/j.biombioe.2014.05.013

864Zdobnov, E.M., Apweiler, R., 2001. InterProScan - An integration platform for the signature865recognition methods in InterPro. Bioinformatics 17, 847-848.

866https://doi.org/10.1093/bioinformatics/17.9.847

867Zhang, H., Zhang, S., He, F., Qin, X., Zhang, X., Yang, Y., 2016. Characterization of a 868manganese peroxidase from white-rot fungus Trametes sp.48424 with strong ability of 869degrading different types of dyes and polycyclic aromatic hydrocarbons. J. Hazard. Mater. 870320, 265-277. https://doi.org/10.1016/j.jhazmat.2016.07.065 
871Zheng, F., An, Q., Meng, G., Wu, X.-J., Dai, Y.-C., Si, J., Cui, B.-K., 2017. A novel laccase

872 from white rot fungus Trametes orientalis: Purification, characterization, and application. Int.

873J. Biol. Macromol. 102, 758-770.

\section{4https://doi.org/http://dx.doi.org/10.1016/j.ijbiomac.2017.04.089}

875Zheng, Y., Zhao, J., Xu, F., Li, Y., 2014. Pretreatment of lignocellulosic biomass for enhanced 876biogas production. Prog. Energy Combust. Sci. 42, 35-53.

877 $\underline{\text { https://doi.org/10.1016/j.pecs.2014.01.001 }}$

878Zhuo, R., Yuan, P., Yang, Y., Zhang, S., Ma, F., Zhang, X., 2016. Induction of laccase by metal 879ions and aromatic compounds in Pleurotus ostreatus HAUCC 162 and decolorization of 880different synthetic dyes by the extracellular laccase. Biochem. Eng. J. 117:62-72.

881https://doi.org/10.1016/j.bej.2016.09.016

882Žužek, M.C., Maček, P., Sepčić, K., Cestnik, V., Frangež, R., 2006. Toxic and lethal effects of 883ostreolysin, a cytolytic protein from edible oyster mushroom (Pleurotus ostreatus), in rodents. 884Toxicon 48, 264-271. https://doi.org/10.1016/j.toxicon.2006.05.011

885

886

887

888

889

890

891

892 


\section{FIGURE CAPTIONS}

894Fig. 1. Schematic representation of experimental set-up.

895Fig. 2. A heatmap representing the ability/efficiency of selected fungal strains to grow on 896autoclaved (A-DIS) and non-autoclaved (NA-DIS) deinking paper sludge. 0 - no growth 897observed in any of the inoculated samples, 1 - mycelium observed in less than half of the 898samples, 2- mycelium overgrew more than $50 \%$ of the samples, 3- mycelium overgrew more 899than $75 \%$ of the samples $(\mathrm{N}=4)$.

900Fig. 3. Degradation/oxidation zone diameters around secreted enzyme extracts (SEEs) from 901different fungal strains applied on screening plates indicating endoglucanase (red), xylanase 902(grey) and laccase (blue) activities. Results represent an average values \pm standard deviations 903from 3 biological replicates. Different capital letters above solid bars denote significant $(P<$ 9040.05) differences in endoglucanase activity, while different lowercase letters above hollow 905bars denote significant $(P<0.05)$ differences in laccase activity.

906Fig. 4. Activities of target lignocellulolytic enzymes (EA) in P. ostreatus PLAB at different 907stages of its growth. A: glycoside hydrolase (endoglucanases, xylanases), B: laccase (ABTS908oxidases). Results represent an average values \pm standard deviations from 3 biological 909replicates.

910

911

912

913

914 
915Table 1. Properties (composition) of deinking sludge (DIS) used as a substrate for selected 916fungal strains.

917

\begin{tabular}{lr}
\hline Parameter & \multicolumn{1}{l}{ Value } \\
\hline $\mathrm{pH}$ & \multicolumn{1}{c}{8.6} \\
\hline Dry content (DC) & $61.35 \%$ \\
Total organic carbon (TOC) & $34.53 \%\left(\mathrm{w} / \mathrm{w}_{\mathrm{DC}}\right)$ \\
Total nitrogen (TON) & $1.48 \%\left(\mathrm{w} / \mathrm{w}_{\mathrm{DC}}\right)$ \\
\hline Cellulose content & $34.2 \%\left(\mathrm{w} / \mathrm{w}_{\mathrm{DC}}\right)$ \\
Lignin content & $6.2 \%\left(\mathrm{w} / \mathrm{w}_{\mathrm{DC}}\right)$ \\
Hemicellulose content & $3.7 \%\left(\mathrm{w} / \mathrm{w}_{\mathrm{DC}}\right)$ \\
\hline Copper (Co) & $64.99 \mathrm{mg} / \mathrm{kg} \mathrm{DC}$ \\
Zinc (Zn) & $84.90 \mathrm{mg} / \mathrm{kg} \mathrm{DC}$ \\
Cadmium (Cd) & $0.40 \mathrm{mg} / \mathrm{kg} \mathrm{DC}$ \\
Chromium (Cr) & $11.60 \mathrm{mg} / \mathrm{kg} \mathrm{DC}$ \\
Nickel (Ni) & $2.20 \mathrm{mg} / \mathrm{kg} \mathrm{DC}$ \\
Lead (Pb) & $17.04 \mathrm{mg} / \mathrm{kg} \mathrm{DC}$ \\
Mercury (Hg) & $0.09 \mathrm{mg} / \mathrm{kg} \mathrm{DC}$
\end{tabular}

918

919

920

921

922

923

924

925

926

79 
927Table 2. Major fungal proteins likely involved in the degradation of deinking sludge (DIS) 928identified in the secretome extracts of P. ostreatus PLAB grown on A-DIS.

\begin{tabular}{lllcccc}
\hline $\begin{array}{c}\text { Protein hits } \\
\text { (fungal } \\
\text { enzymes) }\end{array}$ & $\begin{array}{c}\text { Accession } \\
\text { No. (NCBInr) }\end{array}$ & $\begin{array}{c}\text { Mw } \\
{[\mathbf{k D a}]}\end{array}$ & pI & $\begin{array}{c}\text { Detected } \\
\text { in } \\
\text { band(s) }\end{array}$ & $\begin{array}{c}\text { Matching } \\
\text { Peptides } \\
\#\end{array}$ & $\begin{array}{c}\text { Peptide } \\
\text { scores }\end{array}$ \\
\hline Laccase & CAC69853 & 57.4 & 5.7 & $1,2,3$ & 8 & 308.2 \\
\hline Laccase 2 & Q12739 & 56.7 & 4.7 & 1,2 & 1 & 132.7 \\
\hline Cellobiohydrolase & AAA50608 & 46.1 & 4.8 & 2 & 1 & 90.0 \\
\hline Bilirubin oxidase & BAA85185 & 56.8 & 4.6 & 1,2 & 3 & 158.8 \\
\hline Feruloyl esterase & CDI44666 & 59.3 & 6.9 & 1 & 2 & 159.6 \\
\hline Peptidase 1 & ACR25273 & 38.7 & 7.9 & 3 & 3 & 84.5 \\
\hline 9 & & & & & &
\end{tabular}

930

931

932

933

934

935

936

937Fig. 1 


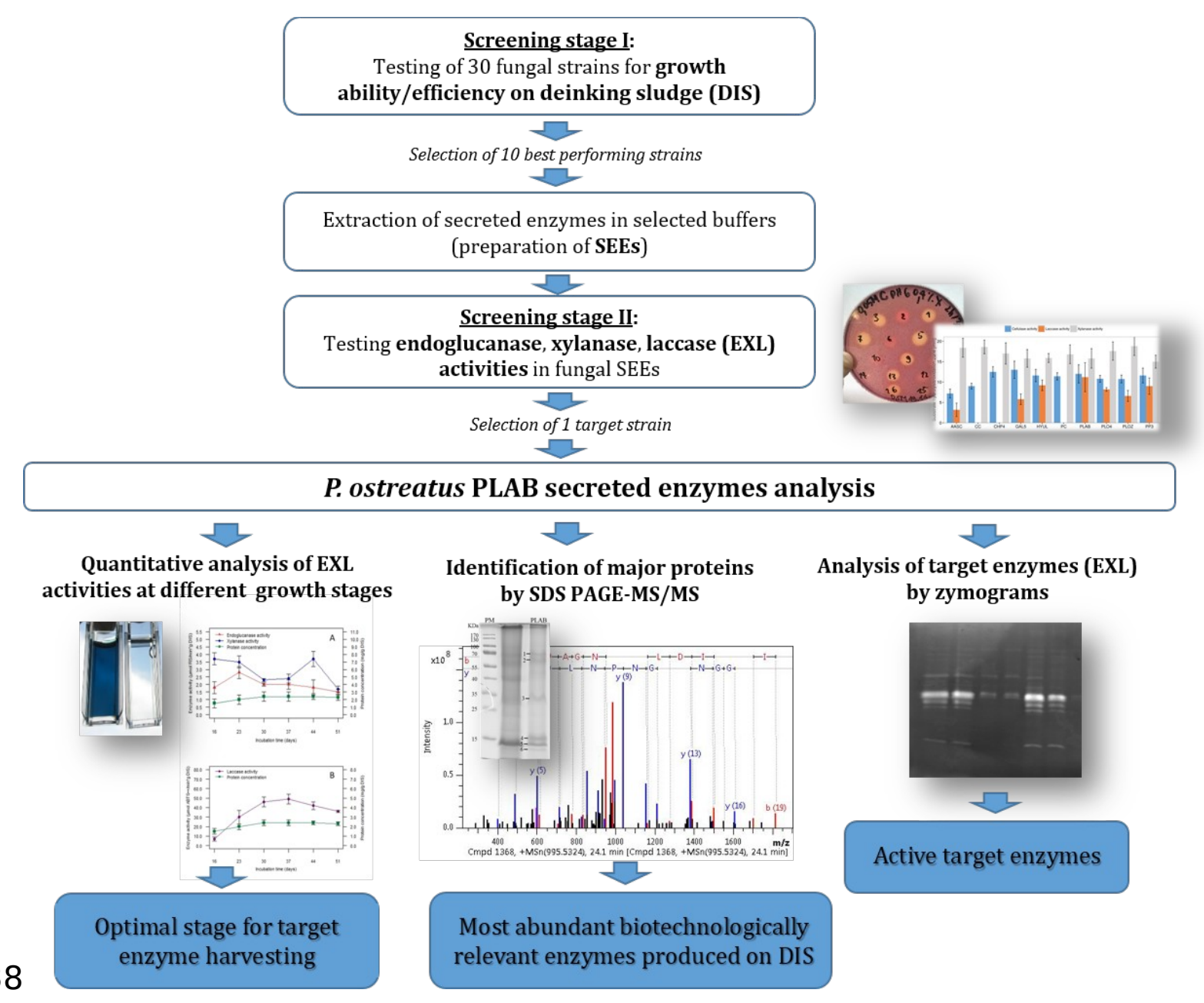

939

940

941

942

943

944

945

946Fig. 2 


\begin{tabular}{|c|c|c|c|}
\hline Species & $\begin{array}{l}\text { Strain } \\
\text { accesion code }\end{array}$ & A-DIS & NA-DIS \\
\hline Agaricus bisporus & AGB1 & 1 & 0 \\
\hline Agrocybe aegerita & AASC & 2 & 1 \\
\hline Auricularia auricula & AAP3 & 1 & 0 \\
\hline Auricularia sambucina & AS & 0 & 0 \\
\hline Chondrostereum purpureum & $\mathrm{CHP} 4$ & 2 & 0 \\
\hline Coprinus comatus & $\mathrm{CC}$ & 2 & 0 \\
\hline Cordyceps militaris & $\mathrm{CM} 2$ & 0 & 0 \\
\hline Fomes fomentarius & FF366 & 1 & 0 \\
\hline Ganoderma lucidum & GAL5 & 2 & 1 \\
\hline Gleophyllum trabeum & GT & 0 & 0 \\
\hline Grifola frondosa & GF5 & 0 & 0 \\
\hline Grifola frondosa & GF2 & 0 & 0 \\
\hline Hypsizygus ulmarius & HYUL1 & 2 & 1 \\
\hline Inonotus obliquus & IO & 1 & 0 \\
\hline Lentimula edodes & LE3770 & 0 & 0 \\
\hline Lentinula edodes & LE7401 & 0 & 0 \\
\hline Meripilus giganteus & MG2 & 1 & 0 \\
\hline Monascus ruber & M2 & 0 & 0 \\
\hline Pleurotus eryngii & POE1 & 1 & 1 \\
\hline Pleurotus ostreatus & PLO4 & 2 & 1 \\
\hline Pleurotus ostreatus & PLAB & 3 & 1 \\
\hline Pleurotus ostreatus & $\mathrm{H} 35$ & 2 & 1 \\
\hline Pleurotus pulmunarius & PP3 & 2 & 0 \\
\hline Pleurotus sp. & PLOZ & 2 & 1 \\
\hline Polyporus umbellatus & PLUI & 0 & 0 \\
\hline Polyporus ciliatus & $\mathrm{PC}$ & 2 & 0 \\
\hline Poria vaillantii & PV2 & 0 & 0 \\
\hline Psilocybe cubensis & PSCUII. & 0 & 0 \\
\hline Trametes versicolor & TVER & 1 & 0 \\
\hline Wolfiporia cocos & DSM1216 & 0 & 0 \\
\hline
\end{tabular}

954Fig.3 


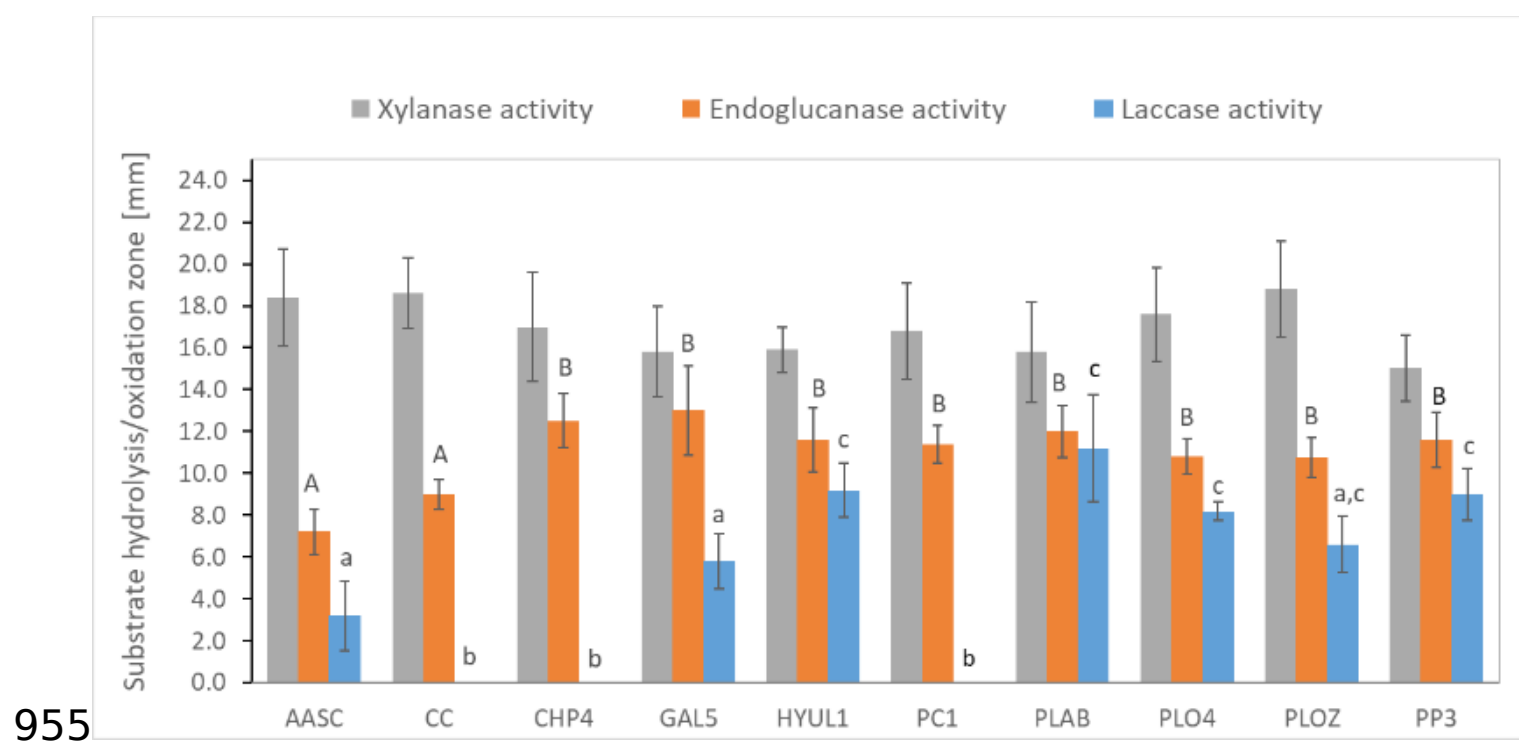

956

957

958

959

960

961

962

963

964

965

966

967

968Fig. 4

87 

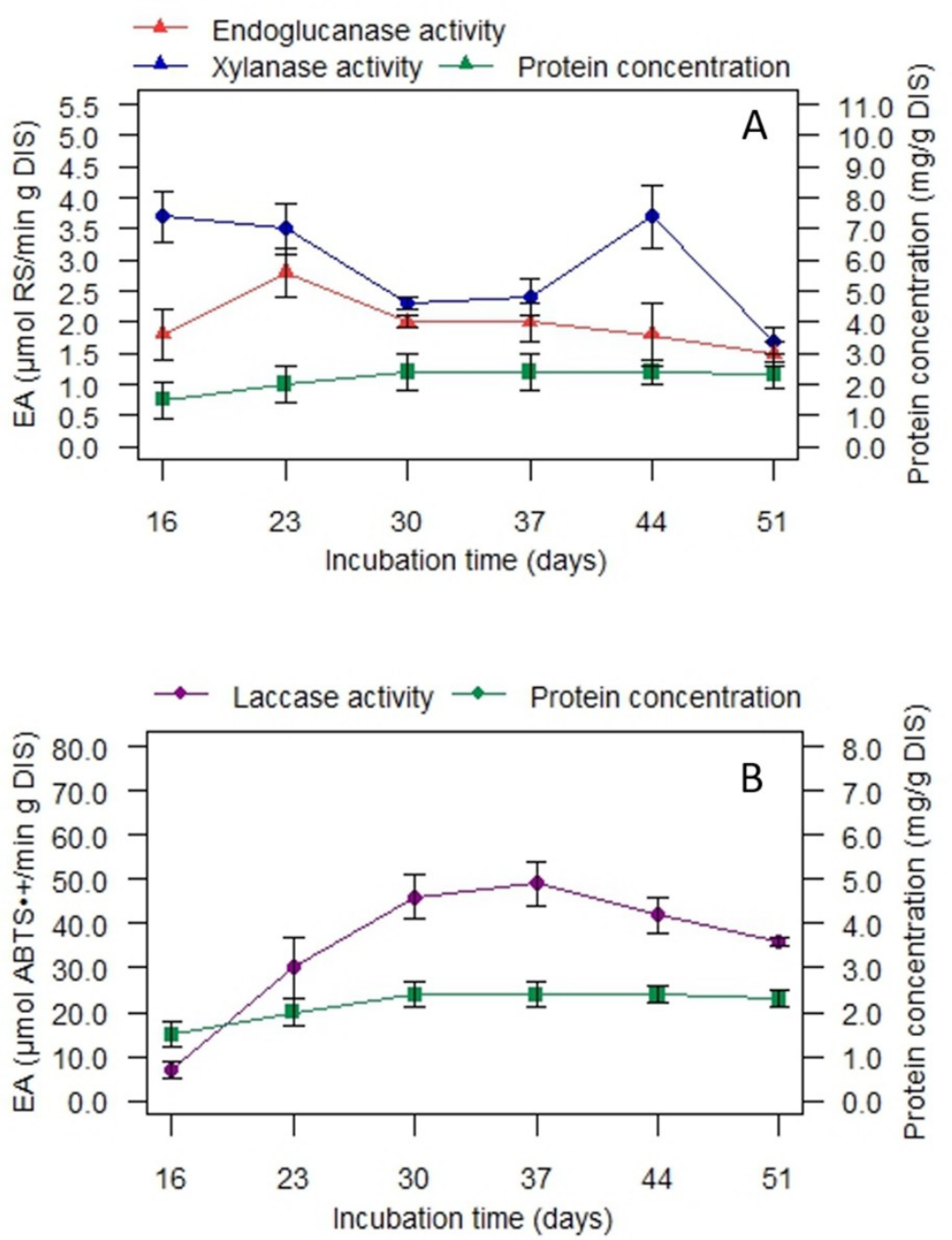

969

970 